\title{
コンクリートの圧縮域における破壊条件*
}

\author{
小林 昭一** 小柳洽**
}

\section{Failure Criterion of Concrete Subjected to Multi-Axial Compression}

by

\author{
Shoichi Kobayashi and Wataru Koyanagi \\ (Faculty of Engineering, Kyoto University, Kyoto)
}

\begin{abstract}
Based on the postulate of stability of materials failure criteria of macroscopically homogeneous isotropic brittle materials under combined stresses are represented by convex surfaces in the principal stress space.

The failure surfaces of both high- and low-strength concretes were compared in the compression rarge as the maximum first stress invariant up to 5.2 times of the uniaxial compressive strength.

The surfaces of the both concretes are almost identical when they are represented in the nondimensional principal stress space, thoúgh their absolute values are quite different.

The surfaces are convex and have the space diagonal as a threefold rotation axis.

Right sections of the surfaces are slightly bulged from equilateral triangles and expand almost isotropically with a decreasing ratio as the hydrostatic pressure increases.
\end{abstract}

(Received May 13, 1967)

\section{1 まえがき}

組合せ応力状態における材料の破壊条件は，棈造体 の終局強度に関する安全性を推定する重要な基礎資料 である.コンクリートの破壊条件に関しては従来種々 の研究や提案がなされているが，その結果はいずれも 特殊な場合や非常に限られた範囲内でしか成立せず， 一般的な破壊条件とはい壳ない。

コンクリートは骨材とセメントと水とのそれぞれ異 質な物質のセメント水和作用による結合体であって， 微視的には非均質異方性である。したがって，コンク リートの破䏅機構は複雑多様であり，その一般的な破 壊条件を求めることは非常に困難である。しかしなが ら，コンクーリトが視的に等方均質とみなせる応力 ならびに環境条件の下で，かつ時間効果の無視できる （すなわち応力レベルがあまり高くない）場合には， その巨視的破䏅条件は三次元主応力空間内の凸曲面 （以後これを破壊曲面と呼ぶ）として一義的に決定で きる.

著者らは，上記の考えに基づいて，破壊に対してセ メントペーストの性質が重要な役割を果たすと考えら れる富配合コンクリートと，骨材の性質，かみ合わせ

* 原稿受理 昭和 42 年 5 月 13 日

** 正 会員 京都大学工学部 京都市左京区吉田本町
が重要な役割を果たすと考光られる貧配合コンクリー トの 2 種類について，種々の三軸組合せの圧縮試験を 行ない，てれをもとに普通コンクリートの圧縮域での 一般的な破壊条件としての破壊曲面形を決定した。

\section{2 実験}

\section{$2 \cdot 1$ 実験計画}

本文の目的は貧富両配合のコンクリートについて， 巨視的破壊条件としての破壊曲面形を決定するととで ある．てのため試験は立方供試体を用い，主として三 軸圧縮試験によった，ての三軸圧縮試験に加えて，同 じ供試体による単軸圧縮試験および二軸圧縮試験を行 なった，また，立方供試体の試験值との比較ならびに バッチ間の変動の有無を調べる目的で円柱供試体を作 成し, 通常の圧縮強度および弓張 (割裂) 強度を求めた。 なお，実験に用いた供試体個数は，富配合（以下A配 合と略）コンクリートでは，立方供試体約 190 個，円 柱供試体約80個であり, 貧配合 (以下 B 配合と略) コン クリートでは，立方供試体約 150 個，円柱供試体約 60 個であった。

\section{$2 \cdot 2$ 使用材料および試験方法}

使用材料は，普通ポルトランドセメント(大阪社製) および吉野川産砂，砂利である。骨材の物理的性質を Table I 亿示す. 
Table I. Physical properties of aggregates.

\begin{tabular}{|c|c|c|c|c|c|c|c|c|c|c|c|}
\hline \multirow{2}{*}{ Kind } & \multirow{2}{*}{$\begin{array}{l}\text { Specific } \\
\text { gravity }\end{array}$} & \multirow{2}{*}{$\begin{array}{c}\text { Unit } \\
\text { weight } \\
\left(\mathrm{kg} / \mathrm{m}^{3}\right)\end{array}$} & \multicolumn{8}{|c|}{ Retaining portion in sieves (\%) } & \multirow{2}{*}{$\begin{array}{l}\text { Fineness } \\
\text { modulus }\end{array}$} \\
\hline & & & 15 & 10 & 5 & 2.5 & 12 & 0.6 & 03 & 0.15 & \\
\hline Sand & 258 & 1715 & 0 & 0 & 0 & 16 & 34 & 58 & 81 & 97 & 286 \\
\hline $\begin{array}{l}\text { Gravel } \\
(5-10 \mathrm{~mm})\end{array}$ & 258 & 1655 & 0 & 1 & 95 & 100 & 100 & 100 & 100 & 100 & 596 \\
\hline $\begin{array}{l}\text { Gravel } \\
(10-15 \mathrm{~mm})\end{array}$ & 258 & 1567 & 0 & 85 & 100 & 100 & 100 & 100 & 100 & 100 & 6.85 \\
\hline
\end{tabular}

Table II. Mix proportions of concrete.

\begin{tabular}{|c|c|c|c|c|c|c|c|c|}
\hline \multirow{2}{*}{ Mix } & \multirow{2}{*}{$\underset{(\mathrm{mm})}{\text { Miax. size }}$} & \multirow{2}{*}{$\underset{\left(\mathrm{kg} / \mathrm{m}^{3}\right)}{C}$} & \multirow{2}{*}{$\begin{array}{c}W \\
\left(\mathrm{~kg} / \mathrm{m}^{\mathrm{s}}\right)\end{array}$} & \multirow{2}{*}{$\begin{array}{l}w / c \\
(\%)\end{array}$} & \multirow{2}{*}{$\begin{array}{l}c / a \\
(\%)\end{array}$} & \multirow{2}{*}{$\underset{\left(\mathrm{kg} / \mathrm{m}^{3}\right)}{S}$} & \multicolumn{2}{|c|}{$G\left(\mathrm{~kg} / \mathrm{m}^{3}\right)$} \\
\hline & & & & & & & $5 \sim 10 \mathrm{~mm}$ & $10 \sim 15 \mathrm{~mm}$ \\
\hline A & 15 & 418 & 184 & 44 & 50 & 860 & 287 & 573 \\
\hline B & 15 & 200 & 164 & 82 & 51 & 982 & 313 & 629 \\
\hline
\end{tabular}

貧富両配合コンクリートの示方配合を Table II に 示す.

$\mathbf{2} \cdot \mathbf{2} \cdot \mathbf{1}$ 供試体作成 コンクリートの練り混ぜに は 2 切可傾式乏キサを使用し，1回の打設量は $10.5 \mathrm{~cm}$ 立方供試体 16 個, $\phi 10 \times 20 \mathrm{~cm}$ 円柱供試体 8 本である. なお，打設時スランプは，A配合コンクリートでは 2.5〜 $5 \mathrm{~cm}$ ，B配合コンクリートでは $1 〜 2 \mathrm{~cm}$ であ った，型わくには 2 層に詰め，振動締固めを行なった。

$\mathrm{A}$ 配合コンクリートは打設後約 4 時間後にみがきガ ラス板を用いて供試体上面を平滑にした。 B配合コン クリートでは約 6 時間後に同方法で表面仕上を行なっ た.

供試体は打設後 24 時間を経て脱型し，ただちに恒温 恒湿室（温度 $20 \pm 1^{\circ} \mathrm{C}$ ，湿度 $90 \pm 5 \%$ ）飞移し，材令 26日まで水中養生し，1 日間同室内で空中養生を行な った後, 材令28日で載荷試験を行なった。

$\mathbf{2} \cdot \mathbf{2} \cdot 2$ 試験方法 立方供試体圧縮試験は, 島津製 Riehlé 型三軸圧縮試験機を用いた。試験機の詳細は 文献 2 を参照されたい.

供試体端面と載荷板間の摩擦の影響を減少させるた め，両面にシリコングリースを凃布したゴムシート (0.23 mm厚)を使用した。乙れにより見掛けの摩擦係 数は0.008〜0.012となり, 減摩材を使用しない場合（推 定摩擦係数0.46〜0.65) の約 $2 \%$ に減少できる。

単軸載荷試験は, 二軸, 三軸試験に対する基準值を 求める目的で行ない，10.5 cm 立方供試体を $10 \times 10 \mathrm{~cm}$ 載荷板を用いて偩荷した。乙れは全面載荷ではないが， 予備試験の結果破壊強度, 破壊の様相ともにほとんど 差がなかったてとから，本実験に用いた部分載荷の状 海の下では全面載荷に非常に近い結果が得られている と考えてよい. 二軸, 三軸試験も同様の部分載荷であ
るが，同じ理由により近似的に全面載荷と同じと考え られる。

二軸載荷試験は, 荷重比を $P_{1} / P_{2}=1 / 1,3 / 4,1 / 2,1 / 4$, $1 / 10$ と変えた比例載荷を主体とした。 なお, 載荷経路 の破壊強度に及ぼす影響を求めるため, 一方向荷重を 一定に保持しながら他方を負荷する定順序載荷，なら びに任意の荷重経路による載荷試験をも行なった. 任 意負荷の荷重経路の例を Fig. 1 に示す.

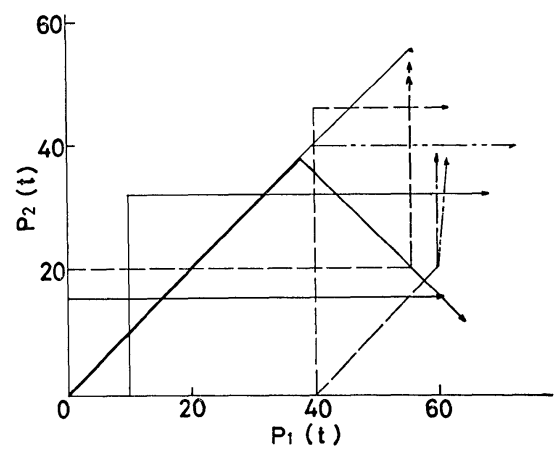

Fig. 1. Loading paths in biaxial test (Proportional loading paths are excluded).

三軸載荷試験は主応力和 $I_{1}$ 一定面内での載荷を主 体とした. すなわち Fig. 2 における OP すなわち静 水圧線 $\left(\sigma_{1}=\sigma_{2}=\sigma_{3}\right)$ 亿沿って所定の主応力和まで載 荷した後, その主応力和を一定に保ちながら主応力の 変化分を一定の比で破壊に至るまで変化させた。

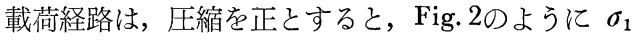
$=\sigma_{2}>\sigma_{3}$ を Case 1 とし, $\sigma_{1}>\sigma_{2}=\sigma_{3}$ を Case 5 とし， この間をほぼ等分するように Case 2,3,4 を選んだ. 主応力和の值は破壊曲面を求めるのに必要な断面数, および試験機容量を考慮して，AB 両配合コンクリー 
Table III. $I_{1} / \sigma_{0}$ values selected.

\begin{tabular}{|c|c|c|c|c|c|c|c|}
\hline Mix A & 1.50 & 225 & 249 & 299 & 3.74 & 449 & 524 \\
\hline Mix B & 183 & 219 & 2.75 & 391 & 4.38 & & \\
\hline
\end{tabular}

$I_{1}=\sigma_{1}+\sigma_{2}+\sigma_{3} ;$ First stress invariant

$\sigma_{0}$; Uniaxial compressive strength

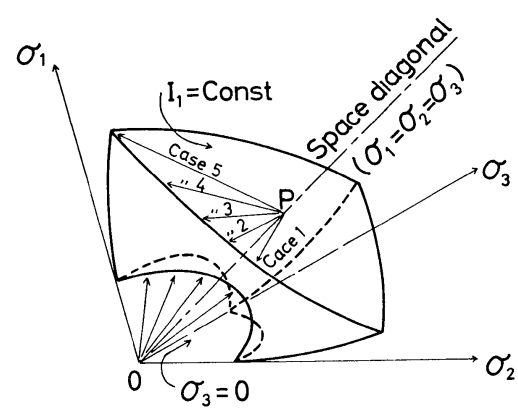

Fig. 2. Loading paths in triaxial test (Sequent and arbitrary loading paths are excluded).

トについて Table III のように選んだ。なお三軸試 験においても，載荷経路の影響を調べるため，定順序 載荷ならびに任意載荷の試験をあわせて行なった。

荷重載荷速度は, 全強度試験を通じて最大主応力の 変化速度を $3 \sim 4 \mathrm{~kg} / \mathrm{cm}^{2} / \mathrm{sec}$ とした. ただし, 三軸試 験で静水圧線に沿う載荷の場合は $4 \sim 6 \mathrm{~kg} / \mathrm{cm}^{2} / \mathrm{sec}$ で ある.

\section{3 試験結果および考察 \\ 3.1 単軸圧縮試験}

立方供試体の単軸圧縮強度はA配合コンクリートで は $436 \mathrm{~kg} / \mathrm{cm}^{2}$ (27個の平均值, 変動係数 $8.0 \%$ ), B配 合コンクリートでは $149 \mathrm{~kg} / \mathrm{cm}^{2}$ (19個の平均, 変動係 数 $5.8 \%$ ) であった. A配合コンクリートでは, てれ を以後の二軸, 三軸圧縮試験の無次元化の基準值とし て採用した。 B 配合コンクリートでは打設時期の異な る供試体では単軸圧縮強度に若干の変動があるため, これについては以後の二軸, 三軸圧縮試験の基準值と してそれぞれの試験に対応する単軸圧縮強度を採用し ている。

立方体単軸圧縮試験による供試体の破壊の様相は, $\mathrm{A} ・ \mathrm{~B}$ 両配合コンクリートともに同じであり, いずれ も負荷方向に対して平行な無数の柱状縦割れを示して いる，ただし，圧縮強度の差により，A配合供試体で は瞬間的な爆裂飛散を生じたが， B 配合では破壇音も 小さく飛散片は生じなかった。これらは供試体の変形 能の差に関連すると考えられるが，変形が測定されな かったので，その差を明確に表わすととはできない.

\section{$3 \cdot 2$ 二軸圧縮試験}

二軸圧縮試験結果を, 立方供試体単軸圧縮強度 $\sigma_{0}$ と の比として無次元化し Fig. 3 亿示す. 図中白丸は比例 載荷による值を, 黒丸は任意載荷を含む定順序載荷に よるものを示す， A・B両配合コンクリートともに, 中間主応力 $\sigma_{2}$ の増加とともに $\sigma_{1}$ は増大し， $\sigma_{2} / \sigma_{0}=$ $0.6 \sim 0.7$ 付近で最大值 $\sigma_{1} / \sigma_{0}=1.3 \sim 1.4$ となり， $\sigma_{1}=$ $\sigma_{2}$ では, $\sigma_{1} / \sigma_{0}=\sigma_{2} / \sigma_{0}=1.1 \sim 1.2$ となる. 実験結果の ばらつきは本質的なもので, 載荷経路による差はみら れない，また，破壊の様相はいずれも自由面におおむ ね平行な薄片状となる。

二軸圧縮試験の結果から中間主応力の破壊に及ぼす 影響を求める試みが数多くなされているが，Fig. 3 の

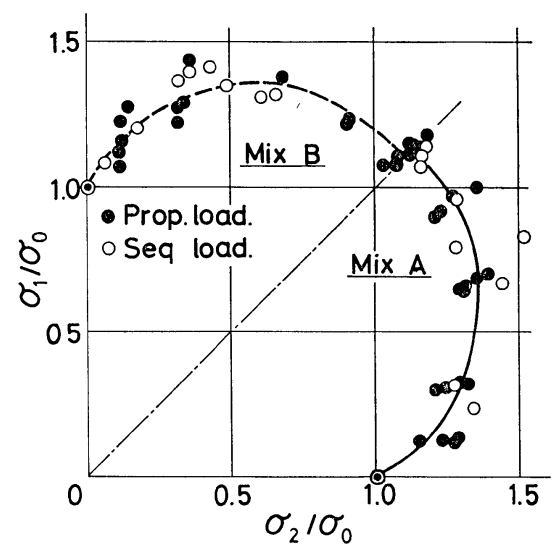

Fig. 3. Test results of biaxial tests for Mix A(High strength) and Mix B(Low strength) concretes.

曲線は, 三次元主応力空間における破壊曲面の $\sigma_{3}=0$ という切口曲線であるととを考えると，てのような材 料の破壤条件については破壊曲面のみを考光ればよく， 中間主応力が破壊に寄与するかしないかという論議に は本質的な意味がない.

\section{$3 \cdot 3$ 三軸圧縮試験}

三軸圧縮試験においては供試体に自由面が残されて いないため, 破壊はA配合コンクリートにおいても単, 二軸圧縮試験のような瞬間的な爆裂飛散の現象は生じ ないが，本試験の範囲内では主応力和一定面内での載 荷中において上昇荷重の急激な低下があり，ての破壊 点は容易に求められた。また, 三軸載荷試験は単, 二 軸載荷に比べてばらつきが少なく安定であった。しか 


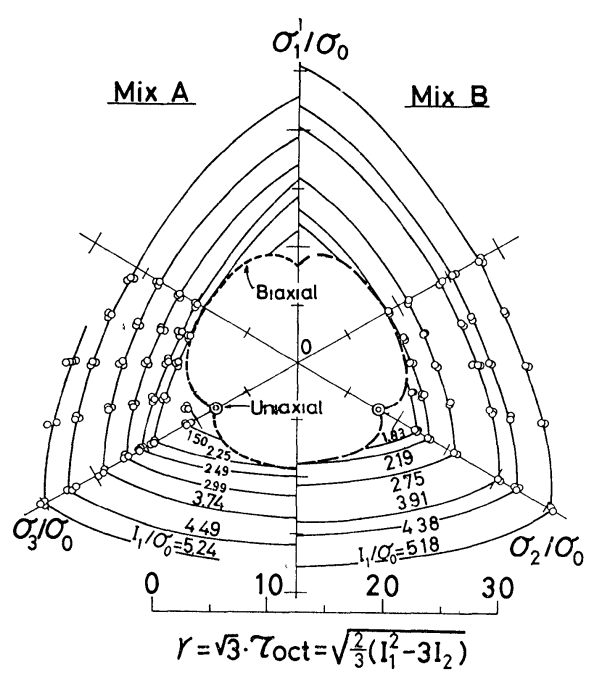

Fig. 4. Right sections of Mix A and Mix B concretes.

(a)

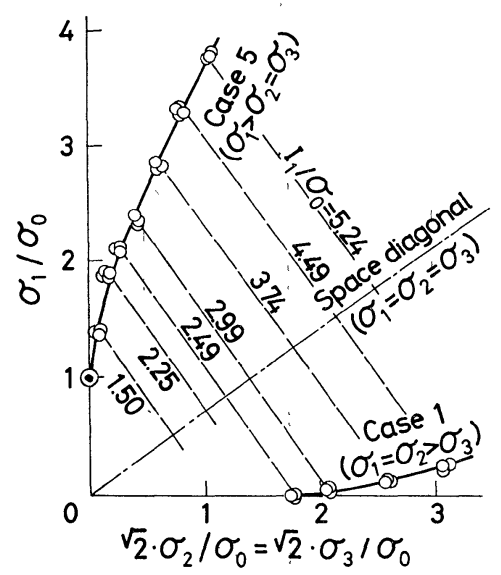

(b)

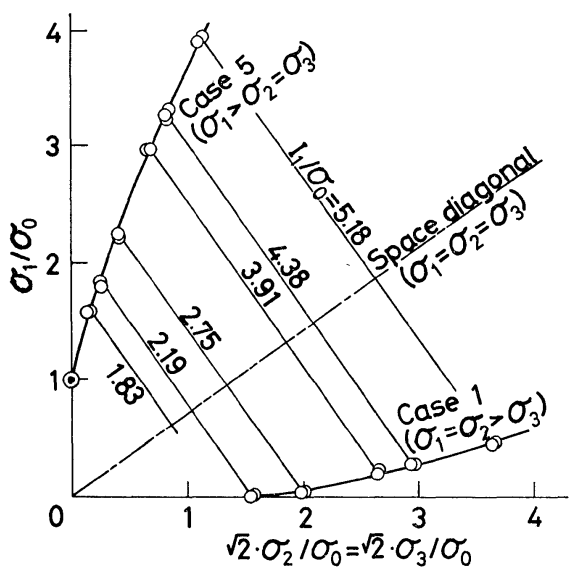

Fig. 5. Rendulic stress curves of (a) Mix A and (b) Mix B concretes.

しながら静水圧の増加に伴いフローの影響のため主応 力和一定面内での載荷が破䏅曲面の近傍では不安定と なり，このような荷重変動による破壊点の決定が困難
となるととが予借試験の結果から確かめられている。 このような場合にはコンクリートの破猿条件は, 三次 元主応力空間内に一義的に定めることは不可能となり， 主ひずみあるいはそれらの時間微分を，さらには履歴 をも含むものとなろう。

三軸圧縮試験結果は, 立方供試体単軸圧縮強度との 比として無次元化したものを用いる。

無次元化した三次元主応力空間における破㳖曲面を 静水圧線に垂直な主応力和一定面で切った切口曲線 （值截面）を Fig. 4 亿示す.なお, 図中の破線は二軸 圧縮試験の結果を $I I$ 面（主応力和が零の平面）に投影 した形である。すなわち，王縮試験で定められるのは この破線より外側の曲面であり，乙の内側は引張りを も含む試験によって求めるてとが可能となる.

破壊曲面を静水圧線と一主応力軸とを含む平面で切 った切口曲線 (Rendulic の応力曲線) を Fig. 5 亿示 す. 主応力和一定面内での載荷が主体であるため, 試 験值は静水圧線乙垂直な線上で対応する.

この直截面と Rendulic の応力曲線との両者から， 求める三次元主応力空間での破壊曲面が容易に組み立 てられる。

Fig. 6 そA・B 両配合コンクリートの試験結果の八面

(a)
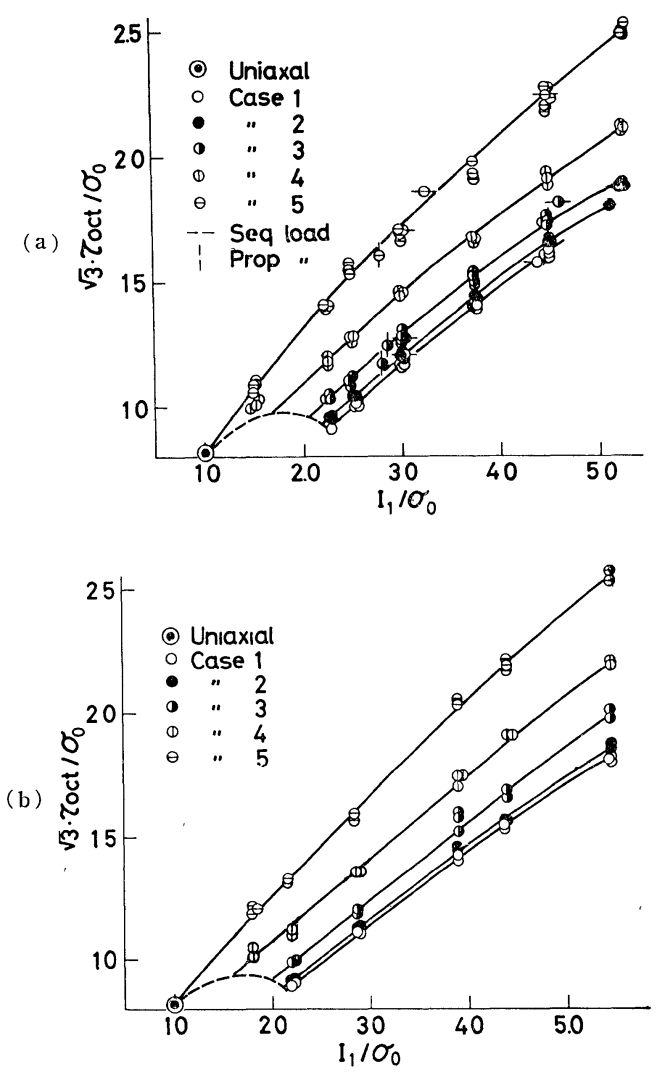

Fig. 6. Representation by octahedral stresses of (a) Mix A and (b) Mix B concretes. 
体応力表示を示す，乙れは静水圧線を含み一つの主応 力軸方向に対し をある傾きを有する数個の平面による 破壊曲面,の切口曲線と考えられる。

て北ら河組み立てられる破壊曲面が，乙てで求め る普通コンクリートの破壤条件である.

Fig. 4 からみて, 破壊曲面Ф形状はA・B 両配合コン クタートともにややふくらんだ三角形状であり，主応 力和（静水圧）の増加につれてての形はほぼ等方的に 増大する: また，その增加割合はしだいに減少する。

これは Rendulic の応力曲線 (Fig.5) からもわかる。 なお，無次元化した破壊曲面に関しては，貧富両配合 コンクリートの差はほとんどみられない。

三軸圧縮試験においても, 破壊曲面の載荷経路に上 る差はまったく認められず, 本試験の応力レベルの範 囲内では三次元主応力空間内に表わした破懐曲面が安 定であるととがわかる。

八面体応力表示によると，載荷の Case ごとにその 曲線形は異なり全体を通じては一義的な関係はみられ ない，すなわち，八面体主応力が一定であっても破壊 時に対応する八面体せん断応力は一定ではない，ある 特定の載荷条件（たとえば $\sigma_{1}>\sigma_{2}=\sigma_{3}$ ) に対しては, 八面体応力表示が破猿曲面の静水圧を含む平面で切口 曲線であるととから, その応力状態のみに対しては, 一義的に八面体応力間の関係が定まるといえる。しか しながら，本試験の結果からわかるように，全応力状 態を含む一義的な関係は得られない，したがって八面 体応力説を一般的なコンクリートの破壊条件として採 用するてとはできない。

Fig. 7 にA・B配合両コンクリートに対する無次元化 した最大最小主応力の和と差との関係を示す。てれら はいずれもほぼ 1 本の同一曲線で近似できるため，乙 の表示在近似的な破壊条件として採用するととが可能 のようにみえる，また，乙れは簡単な変換でMohrの 破瀤仮説と一致する。しかし，コンクリートの破壊を 機構的に考学るとせん断による破懐とは考えられず, また，破壊の様相にもMohr 説から予想される内部 摩擦角の裏づけとなるものがまったく観測されないた め, 平均主応力と最大せん断応力との間の関係で破壞 条件を表わすてとは可能であっても，その物理的な意 味を見いだすととはできない．

三軸圧縮試験による供試体の破猿の様相には Case ごとによる差が認められないとともない，しかしなが ら，てれは供試体が耐荷力を失なった後に生ずる二次 的な現象と考えられ，興味ある傾向が存在しないわけ ではないが，本質的な意味を見いだすととができない． なお，乙の供試体の破断面の觕度はいわ的るせん断角 と一致せず，このととはこれらぜい性材料の破壊が巨 視的にも微視的にも本質的にはせん断破䏅をしないと (a)

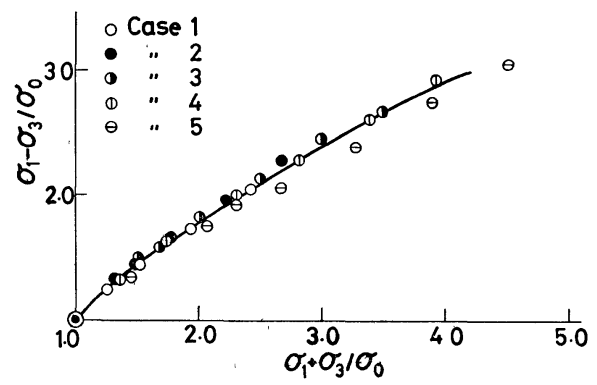

(b)

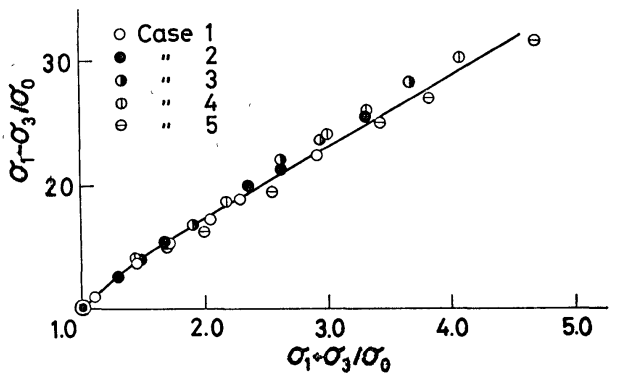

Fig. 7. Relations between sum and difference of maximum and minimum stresses of (a) Mix A and (b) Mix B concretes.

いうことの照査ともなるであろう.

貧富両配合コンクリートについて, 強度の絶対值に は大きな差があり，破䏅の椂相にも結合材の多少から ぐる若干の差はあるが，単軸強度に対する無次元量で 表わした破壊曲面には本質的な差はみられなかった。

てれは圧縮強度が異なるとはい光, 複合材料としてみ たとき両者の材質には極端な差がないため, 結果にも 本質的な相違が生じなかったものといえよう。

\section{4 結 論}

普通コンクリートの破壊条件が三次元主応力空間内 の破壊曲面としてある応力レベルまでは一義的に定め られるとの考察に基づいて行なった実験結果により， 主応力和 $I_{1}$ が単軸圧縮強度 $\sigma_{0}$ の約 5.2 倍までの本実 験の範囲内では破壊曲面は三次元主応力空間内の一凸 曲面として求められた。

なお得られた結論を要約すると次のとおりである。

（1）無次元化した破挤曲面は，貧富両配合コンクリ

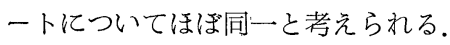

（2）破壊曲面の直截面による切口断面はややふくら んだ三角形状であり，てれは静水圧の増加とともにほ ほ等方的にふくらむ。しかしながら, その増加の割合 は静水圧の増加とともに減少する。

(3) Rendulic の応力曲面は近似的には放物線で表 わされる。なお，てれが直截面での上下限值であるて とから，てれより破壇曲面の概形は容易に推定できる。

（4）本実験の範用の静水圧では破瀤曲面は載荷経路 の影響を受けない。したがって, 安定した載荷試験を 
行なう意味から直截面内での載荷が好ましい.

(5) 破壊条件は近似的には主応力の和の差との関係 で表わすととができ，てれも無次元表示によれば実用 的なコンクリートでは配合による差は認められないも のと考えられる.

\section{5 あ と がき}

前述のように，破壊時の応力レベルがあまり高くな い範囲におけるコンクリートの巨視的破堎条件は，三 主応力空間内の破壊曲面であり，乙れを決定するため に行なった本実験は，上述の制限の下に一般的な試験 である。しかしながら, 静水圧の増加に伴う破壊時応 カレベルの高い場合, ならびに非常に載荷速度が大き い場合または極端に載荷速度が遅い場合については別 に検討する必要があり,てれらの場合には変形も同時
に考慮する必要が生ずるものと考えられる。

本実験の遂行ならびに資料整理に協力をいただいた， 川口興二郎君（現在名古屋鉄道秝）に謝意を表する。 なお，本研究は昭和41年度文部省科学研究費によりな されたものである.

\section{参 考 文 献}

1) Niwa, Y., and S. Kobayashi, Memo. of Faculty of Eng., Kyoto Univ., 29, 1 (1967) ; Niwa, Y., S. Kobayashi, and W. Koyanagi, Memo. of Faculty of Eng., 29, 119 (1967)；丹羽義次，小柳冾， 小林昭一, 土木学会論文集, No. 143, 28 (1967).

2）丹羽義次, 小林昭一, 平島健一, 材料, 1〜，108 (1967).

\section{材料工学}

小野木重治, 足立正雄, 功刀雅長 著

（A 5 判，257ページ，880円，昭和42年 7 月，朝倉書店発行）

著者は本書のまえがきにおいて，技術革新時代の要 請としての「材料工学」について

「しかしながら，材料工学とはいかなる学問をいい， それがいかなる内容をもつべきかは明らかでない，材 料工学は，まだ充分に体系づけられていないからであ る. おそらくこの方面の專門家，教育者の一人一人が それぞれ違った見解をもっているのが現状ではなから うか。著者らが本書を編集，執筆するにあたってまず 最も苦心した点も，材料工学をいかに定義し，てれに いかなる内容を盛るべきかという点であった.」

と述へ，材料の構造と性質との関係，さらにはこれ らと用途との関係を取り扱う科学の一分野を材料科学 (materials science) と呼び，その中で特に工学的な面 を取り扱う部分を材料工学(materials engineering)と している. したがって, 材料工学の目的は, 工業材料 の構造および組織と諸性質との関係を明らかにし，と れらの関係が使用条件によっていかに変化するかを知 り,さらには, 要求される性質を備えた材料を意のま まに生産するてとにあるとしており，材料工学に関す る知識は, もちろん数多く存在する在来の材料の中か ら, 要求される性質を備えた最適の材料を選び出して, これを合理的に利用する上にも, 大いに役だつと述べ
ている。

内容は，第 1 章 工業材料とその一般的性質 (19頁). 第 2 章 金属材料 (144頁) (結晶構造, 平衡状態図, 格 子久陥, 変形, 回復および再結晶, 機械的性質, 顕微 鏡組織と相変態, 熱処理, 表面処理, 実用金属材料と その性質)，第 3 章 セラミック材料 (36頁) (セラミッ ク材料の微構造, 結晶とガラス, 耐火物およびガラス の諸性質, 力学的性質, 熱的性質, 電気的性質, 光学 的性質, 化学的性質)，第 4 章 高分子材料 (52頁) (高 分子物質の構造, 高分子の転移, 高分子材料の応力ひずみ特性, 高分子材料の粘弾性, 結晶性高分子の粘 弾性と流動工学) から成っており，化学構造と基本的 性質の上で非常に典形的なものであるばかりでなく， 最も重要な材料であるとして，金属材料，セラミック 材料および高分子材料がその骨格をなしている.

著者はそれぞれの分野における指導的な研究者, 教 育者であり，ての意欲的な著作は材料工学を学ぶ学生 をはじめ，工業材料を扱う技術者に役だつものである.

上記の三本柱の三種の材料について学んだ後，それ らについて summarize することについては読者にま かされている.

(京都大学工学部航空 田中吉之助) 